Огляди літератури, оригінальні дослідження, погляд на проблему

УДК $616.12-008.331 .1-056.52-06: 616.36 / .361$

DOI 10.11603/1811-2471.2017.v1.i3.8178

\title{
ОСОБЛИВОСТІ ПОРУШЕНЬ ХАРЧОВОЇ ПОВЕДІНКИ ТА ШЛЯХИ ІІЇ НОРМАЛІЗАЦІЇ У ХВОРИХ НА ХРОНІЧНІ ЗАХВОРЮВАННЯ БІЛІАРНОЇ СИСТЕМИ НА ТЛІ ОЖИРІННЯ
}

\author{
○І. А. Якубовська \\ Національна медична академія післядипломної освіти імені П. Л. Шупика
}

РЕЗЮМЕ. В статті наведені дані щодо особливостей харчової поведінки хворих на хронічні захворювання біліарної системи на тлі ожиріння.

Мета. Вивчення впливу індивідуального лікувального комплексу на прояви порушень харчової поведінки.

Матеріал і методи. Обстежено 124 хворих на хронічні захворювання біліарної системи (ХЗБС) на тлі ожиріння.

Результати. Встановлено, що призначення індивідуального дієтичного харчування та фізичної активності сприяють зменшенню клінічних ознак харчової залежності.

Висновки. Розроблений лікувальний комплекс сприяє зменшенню проявів порушень харчової поведінки.

КЛючОВІ СЛОВА: харчова поведінка; дієтичне харчування; фізична активність.

Вступ. Актуальність проблеми харчової поведінки при ожирінні обумовлена тим, що наявність харчової залежності значно утруднює лікування хворих. В рівній мірі це стосується всіх залежних захворювань. У західній літературі для позначення порушень поведінки часто використовують термін «поведінкові аддикції» $[3,4]$.

Розлади харчування при ожирінні обумовлені тривалим надлишком поступлення харчових речовин високої енергетичної цінності, які порушують фізіологічні механізми формування почуттів голоду та насичення. При цьому людина втрачає контроль за кількістю вживаної їжі, потрапляє в залежність від солодощів, жирної їжі та інших страв, які включають декілька продуктів із додаванням приправ, стимуляторів апетиту [1-6].

Харчова поведінка залежить від багатьох факторів, в тому числі від місця, яке займає харчування в ієрархії цінностей людини, значний вплив мають такаж етнокультурні та соціальні чинники. Харчові звички визначаються і традиціями сім'ї та суспільства, національністю, релігійними уявленнями, життєвим досвідом, порадами лікарів, економічними та особистими причинами. Прийняття їжі не завжди пов'язане з угамуванням голоду, їжею нерідко зловживають з метою задоволення широкого спектра інших потреб $[1,2,5,6]$.

Ожиріння $\epsilon$ фактором ризику розвитку захворювань гепатобіліарної системи, включаючи неалкогольну жирову хворобу печінки, гіпотонічну дискінезію жовчного міхура (ДЖМ) та холелітіаз $[5,6,7,9,10,14]$. Серед етіологічних чинників розвитку хронічних захворювань біліарної системи (ХЗБС) на тлі ожиріння негативний вплив мають нераціональне харчування, порушення режиму прийому їжі, зловживання великою кількістю жирних, смажених та надмірно солоних страв [4, $8,9,11]$. Важливим фактором ризику ХЗБС на тлі ожиріння $\epsilon$ гіподинамія, при якій вірогідність роз- витку запального процесу в жовчному міхурі (ЖМ) на 20-50 \% вища, ніж у осіб із високою фізичною активністю $[4,9,12]$.

Мета. Вивчити особливості харчової поведінки та оцінити вплив індивідуального дієтичного харчування і фізичної активності на клінічні прояви харчової залежності у хворих на хронічні захворювання біліарної системи (ХЗБС) на тлі ожиріння.

Матеріал і методи дослідження. Обстежено 124 пацієнти з хронічними захворюваннями біліарної системи (ХЗБС) на тлі ожиріння віком від 31 до 55 років. Хворі на ХЗБС на тлі ожиріння були поділені на дві групи - основну (62 хворих) та контрольну (62 пацієнти). Обидві групи були рандомізовані за віком та статтю. Серед обстежених хворих переважали жінки - 80 (64,5 \%), чоловіків було 44 (35,5 \%). Діагноз захворювання біліарної системи було встановлено у відповідності до протоколів діагностики та лікування хвороб органів травлення на підставі даних анамнезу, клінічного та інструментального обстеження (УЗД органів черевної порожнини, багатофракційного дуоденального зондування - БФДЗ).

Характер харчування оцінювали методом анкетування щодо найтиповіших харчових раціонів пацієнтів за три дні (два робочих і один вихідний) за допомогою триденного щоденника, схваленого МОЗ України 27.10.2014 року. В анкети хворі включали всі продукти харчування та страви, які вони вживали протягом трьох днів. Проводили аналіз анкет з визначенням енергетичної цінності, вмісту білків, вуглеводів, жиру раціонів харчування. Отримані дані порівнювали із рекомендованими потребами в енергії та основними компонентами з урахуванням статі та фізичної активності хворих. Антропометричні дослідження включали визначення ОТ за допомогою сантиметрової стрічки, визначення відсотка жирової та м'язової маси 
Огляди літератури, оригінальні дослідження, погляд на проблему

тіла за допомогою ваг Tanita методом біоелектричного імпедансу. Харчову поведінку хворих оцінювали методом анкетування.

Хворим основної групи з ХЗБС на тлі ожиріння (62 особи) рекомендували індивідуальне дієтичне харчування з помірним обмеженням енергії за рахунок значного зменшення в раціоні вуглеводів, помірного обмеження жиру та збільшення частки тваринного білка, збільшення фізичної активності в залежності від компонентного складу тіла, призначення L-карнітину по 1 г вранці та по 1 г перед фізичними навантаженнями, УДХК в дозі 500 мг на ніч протягом 4 місяців.

Відмінність харчування хворих основної групи полягала у значному збільшенні квоти білка (до 1,6-1,8 г на 1 кг маси тіла), за рахунок нежирного м'яса, птиці та риби, яєчного білка, зменшення в раціоні вуглеводів (до 3 г на 1 кг маси тіла) та нижню норму жиру (1,0-1,2 г на 1 кг маси тіла). Фізична активність полягала у рекомендаціях виконувати вправи, які направлені на збільшення м'язової маси тіла (фітнес) в поєднанні із аеробними навантаженнями.

Пацієнтам контрольної групи (62 хворих) призначали харчування 3 помірним обмеженням енергетичної цінності за рахунок всіх інгредієнтів, УДХК в дозі 500 мг на ніч протягом 4 місяців. Їх раціон відповідав рекомендаціям Наказу МОЗ від 29.10.2013 р. № 931 «Про удосконалення лікувального харчування та роботи дієтологічної системи в Україні»; фізична активність збільшувалась за рахунок аеробних навантажень (ходьба).

Результати й обговорення. Залежно від лікування хворі на ХЗБС на тлі ожиріння були поділені на дві групи-основну та контрольну. В основну групу ввійшли 62 хворих на ХЗБС на тлі ожиріння, яким рекомендували індивідуальне дієтичне харчування з помірним обмеженням енергії за рахунок значного зменшення в раціоні вуглеводів, помірного обмеження жиру та збільшення квоти тваринного білка, призначення L-карнітину по 1 г 2 рази на день протягом 4 місяців, урсодезоксихолевої кислоти в дозі 500 мг на ніч протягом 4 місяців.

Відмінність харчування хворих основної групи полягала у значному збільшенні квоти білка (до 1,6-1,8 г на 1 кг маси тіла) за рахунок нежирного м'яса, птиці та риби, яєчного білка, зменшення в раціоні вуглеводів (до 3 г на 1 кг маси тіла) та нижньої норми жиру (1,0-1,2 г на 1 кг маси тіла). Фізична активність полягала у рекомендаціях виконувати вправи, які направлені на збільшення м'язової маси тіла (фітнес) в поєднанні із аеробними навантаженнями.

В контрольну групу ввійшли 62 хворих, яким призначали харчування з помірним обмеженням енергетичної цінності за рахунок всіх інгредієнтів, урсодезоксихолеву кислоту в дозі 500 мг на ніч протягом 4 місяців. Раціон хворих контрольної групи відповідав рекомендаціям Наказу МО3 від 29.10.2013 р. № 931 «Про удосконалення лікувального харчування та роботи дієтологічної системи в Україні», фізична активність збільшувалась за рахунок аеробних навантажень (ходьба, біг, плавання).

При віднесенні хворих до основної та контрольної груп, крім віку, статі, фізичної активності, враховували також комплаєнтність пацієнтів до змін способу життя, яку оцінювали за 5-бальною системою:

- оцінку 1 бал отримували пацієнти, які вагались в тому, що зможуть щоденно виконувати в повному об'ємі рекомендації щодо харчування та фізичної активності;

- 2 бали - пацієнти, які були схильні частково виконувати дієтичні рекомендації щоденно, проте не були впевнені у виконанні фізичних навантажень;

- 3 бали отримали пацієнти, які були згідні щоденно частково виконувати дієтичні рекомендації та фізичні навантаження;

- 4 бали отримали пацієнти, які запевняли, що 5 робочих днів вони зможуть виконувати дієтичні рекомендації в повному об'ємі та поради щодо фізичної активності протягом 3-4 днів на тиждень;

- 5 балів отримали хворі, які запевняли, що кардинально змінять свій спосіб життя і будуть виконувати всі рекомендації.

Серед хворих на ХЗБС на тлі ожиріння хворі основної групи мали більше бажання та вищу мотивацію дотримуватись в повному об'ємі рекомендацій щодо харчування, збільшення фізичної активності; показник комплаєнтності у хворих даної групи складав $(4,29 \pm 0,37)$ бали і був у 2 рази вищий, порівняно із хворими контрольної групи, $(2,15 \pm 0,17)(P<0,001)$. Аналіз причин низької та високої комплаєнтності пацієнтів на ХЗБС на тлі ожиріння до проведеного лікування залежав від багатьох факторів (табл. 1).

Серед хворих на ХЗБС на тлі ожиріння в основній групі переважали пацієнти з більш високою мотивацією до лікування. Серед пацієнтів цієї групи переважали жителі м. Києва - 72,6 \%, тоді як у контрольній групі більшість пацієнтів були жителями приміських сіл та селищ -61,3\%. Відомо, що жителі міст мають більшу доступність до фітнесклубів, басейнів.

Ще більший вплив на ставлення до лікування мала освіта. Найбільша кількість осіб із вищою освітою була в основній групі хворих. Якщо серед Хворих на ХЗБС на тлі ожиріння в контрольній гру- 
Огляди літератури, оригінальні дослідження, погляд на проблему

Таблиця 1. Фактори, які впливали на комплаєнтність хворих на ХЗБС на тлі ожиріння

\begin{tabular}{|l|c|c|c|c|}
\hline \multirow{2}{*}{ Фактори } & \multicolumn{2}{|c|}{ Основна група (n=62) } & \multicolumn{2}{c|}{ Контрольна група (n=62) } \\
\cline { 2 - 5 } & а6с. к-сть & $\%$ & а6с. к-сть & \% \\
\hline Житель міста & 45 & 72,6 & 24 & 38,7 \\
\hline Житель села & 17 & 27,4 & 38 & 9,7 \\
\hline Вища освіта & 52 & 83,9 & 6 & 90,3 \\
\hline Середня освіта & 10 & 16,1 & 56 & 33,9 \\
\hline Доступні харчові продукти & 46 & 74,2 & 21 & 66,1 \\
\hline $\begin{array}{l}\text { Знижена доступність до харчових } \\
\text { продуктів }\end{array}$ & 16 & 25,8 & 41 & 29 \\
\hline $\begin{array}{l}\text { Обізнаність щодо основ здорового } \\
\text { харчування }\end{array}$ & 50 & 80,6 & 18 & 71 \\
\hline $\begin{array}{l}\text { Необізнаність щодо основ } \\
\text { здорового харчування }\end{array}$ & 12 & 19,4 & 44 & \\
\hline
\end{tabular}

пі відсоток пацієнтів складав 9,7, то в основній групі 83,9 \% хворих мали вищу освіту. 3 рівнем освіти пов'язаний такий фактор як обізнаність щодо основ здорового харчування, яка була високою у хворих основної групи. У основній групі 80,6 \% пацієнтів знали, що не тільки вживання солодощів, але й надмірна кількість в раціоні хліба та каш на тлі гіподинамії буде викликати ожиріння, тоді як у контрольній групі пацієнти були переконані, що гречана, вівсяна каші, молочні продукти, сир не можуть спричинити ожиріння.

Одним із важливих факторів, які впливали на дотримання хворими рекомендацій щодо лікування, була доступність харчових продуктів. Вища матеріальна забезпеченість була у хворих на ХЗБС на тлі ожиріння, які входили до основної групи. 74,2\% хворих основної групи мали можливість щодня купляти м'ясо, рибу, овочі, тоді як кількість таких пацієнтів в контрольній групі була значно нижчою і склала 33,9\%.

Хворим на ХЗБС на тлі ожиріння також рекомендували збільшити фізичну активність. 3 цією метою радили 2 рази на день ходьбу по 30 хвилин, а також вправи з навантаженнями на м'язи. Темп ходьби та вправи призначали з урахуванням віку та переносимості фізичних навантажень (під- рахунок частоти серцевих скорочень шляхом визначення пульсу, вимірювання артеріального тиску). Перед фізичним навантаженням хворі приймали L-карнітин.

Оцінка ознак порушень харчової поведінки показала, що через 4 місяці від початку лікування у більшості хворих на ХЗБС на тлі ожиріння в основній групі сформувались здорові харчові звички (табл. 2). Подолання харчової залежності $€$ найважливішим для лікування хворих із ожирінням, оскільки дозволяє хворому контролювати всі аспекти харчування, включаючи об'єм страв, характер харчування, режим прийому їжі та сприяє утриманню зниженої маси тіла впродовж тривалого часу. Дані, наведені в таблиці 2, показують, що більшість хворих на ХЗБС на тлі ожиріння основної групи подолали через 4 місяці значну кількість ознак харчової залежності.

Після лікування в основній групі хворих на ХЗБС кількість хворих, які швидко їли, зменшилася із 91,9 \% до лікування до 12,9 \% після лікування; кількість хворих із втраченим контролем за кількістю спожитої їжі після лікування зменшилась в основній групі в 4,9 раза, із 79 \% до 16,1 \%. Відсоток хворих із синдромом нічноїїди у хворих на ХЗБС на тлі ожиріння в основній групі хворих зменшився 3

Таблиця 2. Клінічні ознаки порушень харчової поведінки у хворих на ХЗБС на тлі ожиріння

\begin{tabular}{|l|c|c|c|c|}
\hline \multirow{2}{*}{ Симптоми } & \multicolumn{2}{|c|}{$\begin{array}{c}\text { Основна група }(\mathrm{n=62)} \\
\text { абс., \% }\end{array}$} & \multicolumn{2}{c|}{$\begin{array}{c}\text { Контрольна група (n=62) } \\
\text { а6с., \% }\end{array}$} \\
\cline { 2 - 5 } & до лікування & після лікування & до лікування & після лікування \\
\hline Швидкий прийом їжі & $57(91,9)$ & $8(12,9)$ & $56(90,3)$ & $40(64,5)$ \\
\hline $\begin{array}{l}\text { Втрата контролю за } \\
\text { кількістю з"їденого }\end{array}$ & $49(79)$ & $10(16,1)$ & $46(74,2)$ & $38(61,3)$ \\
\hline Вживання їжі в нічний час & $38(61,3)$ & $5(8,1)$ & $40(64,5)$ & $28(45,2)$ \\
\hline Надмірна їда під час стресу & $41(66,1)$ & $6(9,7)$ & $42(67,7)$ & $35(56,5)$ \\
\hline $\begin{array}{l}\text { Надмірна їда при надлишку } \\
\text { вільного часу }\end{array}$ & $60(96,8)$ & $9(14,5)$ & $59(95,2)$ & $49(79)$ \\
\hline Залежність від солодощів & $47(75,8)$ & $11(17,7)$ & $46(74,2)$ & $40(64,5)$ \\
\hline
\end{tabular}


Огляди літератури, оригінальні дослідження, погляд на проблему

61,3\% до 8,1 \%. Після лікування кількість хворих на ХЗБС на тлі ожиріння в основній групі, які збільшували вживання їжі під час стресових ситуацій, зменшилась 366,1 \% до лікування до 9,7 \%.

Після лікування відсоток хворих на ХЗБС на тлі ожиріння в основній групі, які у вихідні та святкові дні займали вільний час вживанням їжі, зменшився із 96,8 \% до 14,5 \%. Якщо до лікування залежність від солодощів відмічали 75,8 \% пацієнтів основної групи, то після лікування тільки у 17,7 \% мала місце харчова залежність від солодкого. Слід також відзначити, що у тих хворих на ХЗБС на тлі ожиріння, які мали ознаки, характерні для харчової залежності, їх вираженість стала меншою, ніж до лікування.

Аналіз показників харчової залежності у хворих на ХЗБС на тлі ожиріння у контрольній групі показав, що відсоток хворих із ознаками харчової залежності в даній групі зменшився незначно і в меншій мірі, порівняно із хворими основної групи. Так, якщо в основній групі кількість пацієнтів, які швидко їли, зменшилась у 7 разів, то у контрольній групі - в 1,4 раза. Кількість хворих на ХЗБС на тлі ожиріння із втратою контролю за кількістю спожитої їжі в основній групі після лікування було в 4,9 раза меншою, порівняно із даними до лікування, у хворих контрольної групи кількість осіб із втраченим контролем за кількістю з'їденого після лікування була тільки в 1,2 раза меншою.

У більшості хворих на ХЗБС на тлі ожиріння контрольної групи після лікування зберігався син- дром нічної їди. Так, якщо в основній групі після лікування кількість хворих із синдромом нічної їди зменшилась в 7,5 раза, то у контрольній групі - в 1,4 раза. Кількість хворих, які вживали надмірну кількість їжі під час стресу та від надлишку вільного часу, у основній групі після лікування зменшилась в 6,8 та в 6,7 раза, у контрольній групі - тільки в 1,2 та в 1,21 раза відповідно.

Подібна тенденція стосується також такої ознаки харчової залежності, як неконтрольований потяг до солодкого. 3 даних, наведених у та6лиці 2, видно, що у хворих на ХЗБС на тлі ожиріння основної групи залежність від солодощів після лікування зустрічалась в 4,2 раза рідше, ніж у хворих контрольної групи - їі частота після лікування зменшилась тільки в 1,1 раза.

Висновки. 1. У хворих на ХЗБС на тлі ожиріння виявлені ознаки порушень харчової поведінки, вираженість яких залежала від освіти пацієнтів, можливостей придбання продуктів харчування з високою біологічною цінністю та обізнаності хворих щодо принципів здорового харчування.

2. Призначення дієти із підвищеним вмістом білка та збільшенням фізичної активності сприяє зменшенню проявів харчової залежності у хворих на ХЗБС на тлі ожиріння основної групи.

3. Формування здорових харчових звичок $\epsilon$ найбільш позитивним в лікуванні хворих на ХЗБС на тлі ожиріння, оскільки дозволить пацієнтам зберегти отримані результати протягом тривалого часу.

\section{ЛІТЕРАТУРА}

1. Вознесенская Т. Г. Клинико-психологический анализ нарушений пищевого поведения при ожирении / Т. Г. Вознесенская, А. В. Вахмистров // Журн. невропат. и психиатр. им. С. С. Корсакова. - 2001. - № 12. - С. 19-24.

2. Литвин-Кіндратюк С. Д. Харчова активність особистості: традиційні й інноваційні стратегії / С. Д. Литвин-Кіндратюк // Збірник наукових праць: філософія, соціологія, психологія. - Івано-Франківськ : Вид-во «Плай» Прикарпатського ун-ту, 2000. - Вип. 5. - Ч. 1. - С. 160-165.

3. Малкина-Пых И. Г. М Терапия пищевого поведения : справочник практического психолога / И. Г. Малкина-Пых. - М. : Эксмо, 2007. - 1040 с.

4. Коннер М. Социальная психология пищи / Марк Коннер, Кристофер Дж. Армитейдж. - Х. : Гуманитарный Центр, 2012. - 264 с.

5. Матвеев А. А. Репрезентация эмоций у больных нервной булимией // Вестн. Моск. ун-та. - 2008. - № 4. C. 38-53.

6. Скугаревский О. А. Нарушения пищевого поведения и возможность их скрининговой оценки / О. А. Скугаревский // Вопросы организации и информатизации здравоохранения. - 2003. - № 3.- С. 41-44.

7. Evaluation of ultrasonographic fatty liver and severity of coronary atherosclerosis, and obesity in patients undergoing coronary angiography / M. Acikel, S. Sunay, M. Koplay [et al.] // Anadolu Kardiyol. Derg. - 2009. - Vol. 9, No. 4. - P. 273-279.

8. Executive summary: standards of medical care in diabetes - 2011 / American Diabetes Association // Diabetes Care. - 2011. - Vol. 34, Suppl. 1. - P. S4-S10.

9. Executive summary: standards of medical care in diabetes - 2013 // Diabetes Care. - 2013. - Vol. 36, Suppl. 1. P. S4-S10.

10. Perazzo $\mathrm{H}$. The interactions of nonalcoholic fatty liver disease and cardiovascular diseases / H. Perazzo, T. Poynard, J. F. Dufour // Clin. Liver Dis. - 2014. - Vol. 18, No. 1. - P. 233-248.

11. Sun L. Association between non-alcoholic fatty liver disease and coronary artery disease severity / L. Sun, S. Z. Lu // Chin. Med. J. (Engl.). - 2011. - Vol. 124, No. 6. - P. 867-872.

12. Targher G. Non-alcoholic fatty liver disease, the metabolic syndrome and the risk of cardiovascular disease: the plot thickens / G. Targher // Diabet. Med. -2007. Vol. 24, No. 1. - P. 1-6. 
Огляди літератури, оригінальні дослідження, погляд на проблему REFERENCES

1. Voznesenskaya, T.G., \& Vakhmistrov, A.V., (2001). Kliniko-psikhologicheskiy analiz narusheniy pishchevogo povedeniya pri ozhirenii [Clinical and psychological analysis of eating disorders in obesity]. Zhurn. nevropat. i psikhiatr. im. S.S. Korsakova - Journal of Neuropathy and Psychiaty named after S.S. Korsakov, 12, 19-24 [in Russian].

2. Lttvyn-Kindratiuk, S.D. (2000). Kharchova aktyvnist osobystosti: traditsiini i innovatsiini stratehii [Nutritional activity of the individual: traditional and innovative strategies]. Zbrnyk naukovykh prats: filosofiia, sotsiolohiia, psykholohiia, Ivano-Frankivsk: Vyd-vo "Play" Prykarpatskoho un-tu - Collection of Scientific Works: Philosophy, Sociology, Psychology - Ivano-Frankivsk: View of the "Plai" of the Carpathian University, 5 (1), 160-165 [in Ukrainian].

3. Malkina-Pykh, I.G., (2007). M-Terapiya pishchevogo povedeniya: spravochnik prakticheskogo psikhologa. [M-therapy of eating behavior: a handbook of practical psychologist]. Moscow: Eksmo [in Russion].

4. Konner, M., \& Armitage, K.J., (2012). Sotsialnaya psikhologiya pishchi [Social psychology of food]. Kharkov: Gumanitarnyy Tsentr [in Russian].

5. Matveyev, A.A., (2008). Reprezentatsiya emotsiy u bolnykh nervnoy bulimiyey [Representation of emotions in patients with bulimia nervosa]. Vestn. Mosk. un-ta. Journal of Moscow University, 4, 38-53 [in Russian].

6. Skugarevskiy, O.A., (2003). Narusheniya pishchevogo povedeniya i vozmozhnost ikh skriningovoy otsenki [Disorders of eating behavior and the possibility of their screening assessment]. Voprosy organizatsii $i$ informatizatsii zdravookhraneniya - Problems of the Organization and Informatization of Public Health, 3, 41-44 [in Russian].

7. Acikel, M., Sunay, S., \& Koplay, M. (2009). Evaluation of ultrasonographic fatty liver and severity of coronary atherosclerosis, and obesity in patients undergoing coronary angiography. Anadolu Kardiyol. Derg., 9 (4), 273-279.

8. (2011). Executive summary: standards of medical care in diabetes - 2011. American Diabetes Association. Diabetes Care, 34 (1), 4-10.

9. (2013). Executive summary: standards of medical care in diabetes - 2013. Diabetes Care, 36 (1), 4-10.

10. Perazzo, H., Poynard, T., \& Dufour, J.F. (2014). The interactions of nonalcoholic fatty liver disease and cardiovascular diseases. Clin. Liver Dis., 18 (1), 233-248.

11. Sun, L., \& Lu, S.Z., (2011). Association between non-alcoholic fatty liver disease and coronary artery disease severity. Chin. Med. J. (Engl.), 124 (6), 867-872.

12. Targher, G. (2007). Non-alcoholic fatty liver disease, the metabolic syndrome and the risk of cardiovascular disease: the plot thickens. Diabet. Med., 24 (1), 1-6.

\title{
ОСОБЕННОСТИ НАРУШЕНИЙ ПИЩЕВОГО ПОВЕДЕНИЯ И ПУТИ ЕГО НОРМАЛИЗАЦИИ У ПАЦИЕНТОВ С ХРОНИЧЕСКИМИ ЗАБОЛЕВАНИЯМИ БИЛИАРНОЙ СИСТЕМЫ НА ФОНЕ ОЖИРЕНИЯ
}

๑И. А. Якубовская

\author{
Национальная медицинская академия последипломного образования имени П. Л. Шупика
}

РЕзЮМЕ. В статье приведены данные об особенностях пищевого поведения больных хроническими заболеваниями билиарной системы на фоне ожирения. Установлено, что назначение индивидуального диетического питания и физической активности способствуют уменьшению клинических признаков пищевой зависимости. Обследовано 124 больных хроническими заболеваниями билиарной системы (ХЗБС) на фоне ожирения. Разработанный лечебный комплекс способствует уменьшению проявлений нарушений пищевого поведения.

Цель. Изучение влияния индивидуального лечебного комплекса на проявление нарушений пищевого поведения.

Материал и методы. Обследовано 124 больных хроническими заболеваниями билиарной системы (ХЗБС) на фоне ожирения.

Результаты. Установлено, что назначение индивидуального диетического питания и физической активности способствует уменьшению клинических признаков пищевой зависимости.

Выводы. Разработанный лечебный комплекс способствует уменьшению проявлений нарушений пищевого поведения.

КЛЮчЕВЫЕ СЛОВА: пищевое поведение; диетическое питание; физическая активность. 


\section{@I. A. Yakubovska}

\section{P. Shupyk National Medical Academy of Postgraduate Education}

SUMMARY. The article presents the results of studies which show that patients with chronic diseases of the biliary system against the background of obesity have disorder of eating behavior. The appointment of an individual therapeutic complex, a diet an increase of physical activity by means of physical and aerobic loads contribute to a loss of clinical signs of food dependence. 124 patients with chronic diseases of the biliary system with obesity were examined. The developed medical complex helps to reduce the manifestations of eating disorders.

The aim. Studying the influence of the individual medical complex on the manifestation of disorders of eating behavior.

Materials and Methods. 124 patients with chronic diseases of the biliary system (ChDBS) were surveyed in obesity.

Results. It has been established that the assignment of individual dietary nutrition and physical activity contributes to the reduction of clinical signs of food dependence.

Conclusions. The developed medical complex contributes to the reduction of manifestations of disorders of eating behavior.

KEY WORDS: eating behavior; nutrition; physical activity. 